Annals of Tropical Research 29[1]:26-42(2007)

(c) LSU, Leyte, Philippines

\title{
Forest carbon stock and livelihood opportunities under the CBFM Project in Midwestern Leyte Province, Philippines
}

\author{
Arturo E. Pasa \\ College of Forestry and Natural Resources, Leyte State University, \\ Baybay, Leyte 6521-A, Philippines
}

\begin{abstract}
The study assessed the carbon stocks or storage within the Community-Based Forest Management (CBFM) Project in Midwestern Leyte Province. The CBFM project area stored an average carbon density of $333 \mathrm{Mg} / \mathrm{ha}$ from aboveground biomass down to the soil complex (0-1m depth). The upperstorey biomass had an average carbon density of $166 \mathrm{Mg} / \mathrm{ha}$ while $1.94 \mathrm{Mg} / \mathrm{ha}$ for the understorey biomass. In addition, floor litter carbon density ranged from $1.38 \mathrm{Mg} / \mathrm{ha}$ to $2.75 \mathrm{Mg} / \mathrm{ha}$, root carbon density from 11.0 to 17.4 , and soil carbon density from 111 to $221 \mathrm{Mg} / \mathrm{ha}$.

The huge amount of carbon stored under the CBFM project is a potential livelihood opportunity for the local people. Several organizations are interested in carbon offset projects where huge amount of fund is involved -- a situation where both farmers and the environment would be benefited.
\end{abstract}

KEYWORDS: environmental services, forest carbon, rewards, livelihood opportunities, CBFM Project

Correspondence: A. E. Pasa Address: College of Forestry and Natural Resources, Leyte State University, Visca, Baybay, Leyte 6521-A, Philippines. Tel. No. (053) 335-4210 DOI: $10.32945 /$ atr2913.2007 


\section{INTRODUCTION}

Forests are important ecosystems providing enormous environmental services to society. As a pollution sink, forests absorb million tons of carbon dioxide annually thereby regulating the concentration of this gas in the atmosphere. As a complex living unit, forests enhance floral and faunal diversity and the associated food web necessary in balancing the intricate global ecosystems. They provide wood, food, medicine, and other major and minor products. Forests also store, filter, and release huge amounts of good quality water for households, farms, hydroelectric power plants, water districts, various industries, and other consuming entities.

However, the undue pressure imposed on forests by the growing population has damaged such ecosystem. Population pressure is also gradually depriving people of the environmental services that they used to enjoy everyday. For instance, the substantial increase in the demand for timber and timber products has depleted the world's forests (Carandang, 1994) including that of the Philippines. In 1975, the country was the world's leading tropical hardwood producer but became a timber-importing nation in 1994 (Chiong-Javier, 2001 cited by Scherr et al., 2004). Hence, the Philippine government has designed various programs to alleviate the country's forests' worsening condition.

One of the programs adopted by the Philippine government is the Community-Based Forest Management (CBFM). Through Executive Order 263 S 1995, CBFM has become the national strategy to ensure the sustainable development of the country's forestland resources. It is aimed to avert the vicious cycle of poverty, which is the main reason for the destruction of the uplands. It is likewise designed to ensure the protection and advancement of the right of the Filipino people to a healthful and balanced ecosystem as provided for under Article II, Section 16 of the 1987 Constitution. Thus, all CBFM Projects are designed not only to uplift the socio-economic condition of the farmers but also to provide environmental services to our society.

One of the environmental services of a CBFM project is the sequestration and storage of carbon dioxide $\left(\mathrm{CO}_{2}\right)$, known in the scientific literature as among the gases responsible for the warming of the atmosphere. $\mathrm{CO}_{2}$ is the most abundant and its proportionate effect is about 49 percent of the global warming (Field, 1997). According to scientific estimates, $\mathrm{CO}_{2}$ concentration will reach the equivalent of 560 parts per million by the year 2030 , which is double than the natural level. With the increasing concentration of this gas, together with other greenhouse gases, temperature of the earth's surface will also increase. Experts reporting during the May 1990 United Nations 
Intergovernmental Panel for Climate Change estimated that by 2020 the world will, on the average, be $1.3{ }^{\circ} \mathrm{C}$ warmer than now and will be rising to $3{ }^{\circ} \mathrm{C}$ by 2070. The sea level will rise because the heat will melt the polar ice and expand the water in oceans. Over the next century, water levels are expected to increase by a meter or more. Many more people are in peril from the flooding of deltas and other-low-lying coastal areas. Some areas are already subsiding, making them doubly vulnerable to the rising sea. On this crowded planet, divided by national frontiers, it will be hard to find anywhere to go (Lean et al., 1990).

Efforts to mitigate climate change are now underway like the greenhouse gas inventory for the land use change and forestry (LUCF) sector in the Philippines, Thailand, and Indonesia as reported by Magcale-Macandog (2000). While the industrial sector is required to reduce carbon emissions from fossil fuels as imposed under the Philippine Clean AirAct, Kyoto Protocol and other related environmental laws and policies, the forestry sector is also trying to find what forest management system is able to address such a problem without jeopardizing the socio-economic development of the forest inhabitants. In line with this noble cause, the sustainable implementation of CBFM projects is viewed as an important contribution of the forestry sector in mitigating climate change.

Forest ecosystems play an important role in the climate change problem because they can both be the sources and sinks of atmospheric $\mathrm{CO}_{2}$ and can be managed to assimilate $\mathrm{CO}_{2}$ via photosynthesis and store carbon in biomass and soil (Lasco, 2003). Great attention is focused on tropical forestry to offset carbon emission due to its cost-effectiveness, high potential rates of carbon uptake, and associated environmental and social benefits (Moura-Costa, 1996; IPCC, 1995; Myers, 1996 cited by Lasco, 2003). Tropical forests have the biggest long-term potential to sequester atmospheric carbon $(80 \%$ of the world's forest total) by protecting forestlands, slowing deforestation, and doing reforestation and agroforestry (IPCC, 1995). Sustaining the said environmental service from tree plantations and agroforestry systems, however, requires a strategy that will keep the stakeholders passionate in providing the same. Concomitantly, rewards or livelihood opportunities are believed to re-energize the interest of the upland people to continue providing such environmental services.

The assessment of environmental services of a CBFM project is a new dimension of providing wider opportunities to the local people for them to 
manage the natural resources in a sustainable manner. The underlying purpose is to intensify further the envisioned sustainability of forest resources and environmental services in the country by giving rewards to the local people involved which RUPES (2002) also envisaged. The generation of these environmental services is a difficult and complex task of the local people. They risk their lives to protect the project against illegal loggers and poachers and to keep environmental services from the CBFM project available to the beneficiaries in the surrounding ecosystems and thus, should be rewarded for this reason. Therefore, quantification of such services particularly carbon sequestration is essential not only to validate that the CBFM project in Midwestern Leyte indeed has provided environmental services to the society but also to serve as basis for rewarding the local people involved. Exploration of possible rewards or livelihood opportunities under carbon trading was also made.

\section{MATERIALS AND METHODS}

\section{Site of the study}

The site of the study is the 2,236-ha Community-Based Forest Management (CBFM) project in Barangay Gabas and Barangay Kilim, Baybay, Leyte. The site lies between $124^{\circ} 45^{\prime}$ longitude and $10^{\circ} 15^{\prime}$ latitude having a climatic type IV with more or less evenly distributed rainfall throughout the year. On the average, June to January are wet months while February to May are relatively dry. The highest rainfall occurs in December and the lowest in March. Average annual temperature ranges from $25.25^{\circ} \mathrm{C}$ to $30.95^{\circ} \mathrm{C}$. The monthly average wind velocity is $2.17 \mathrm{~m}$ per second with the highest occurring during February to March and July that is attributed to the northeast and southeast monsoon (CRMF, undated).

The site is rugged and mountainous with slope ranging from 30 to 80 percent. The highest elevation is $986 \mathrm{~m}$ above sea level at the northeastern part called Mt. Emik. Metamorphic, volcanic, and highly crystallized rocks are dominant geological formations in the area.

The site has a moderately acidic soil $\mathrm{pH}$ from 5.10 to 6.57 . The study of Asio (1996) on the soils of the adjacent mountain ecosystem corroborates such findings. In his analysis, he obtained acidic $\mathrm{pH}$ values ranging from 4.0 to 
5.20. The decomposition of organic materials within the forest floor and uppermost soil horizon normally leads to organic acid formation. And also because of intensive weathering, soils under rainforest are usually acidic. Worldwide observation also revealed that tropical soils are usually acidic due to such phenomenon mentioned earlier as well as the occurrence of high rainfall that removes basic materials or substances through leaching, surface runoff, and soil erosion.

Soil texture ranged from silt loam, sandy loam to clayey. The protected zone contained the highest percentage of silt; the multiple-use zone had the highest percentage of sand; and the buffer zone had the highest percentage of clay. Bulk density,on the other hand, was very low implying that the area was not subjected to various forms of compaction-enhancing perturbations. The protected zone contained the highest percentage of carbon and organic matter followed by the buffer zone and then the multiple-use zone. It was found that the nitrogen level within the different zones showed the same trend as the organic matter. Other nutrients are also present at variable concentrations but sufficient enough to support the growth of plants (Table 1).

The CBFMP site has three land use classifications, namely: 1) protected zone, 2) buffer zone, and 3) multiple-use zone. Table 2 shows the land use classification of the site and their corresponding areas of coverage.

The protected zone, located in the northeast portion covering 1,229.8 ha or about 55 percent of the whole project site, is a wilderness area protected against human interventions. The buffer zone, located immediately adjacent below the protected zone along the southwest orientation, is the portion of the project site where regulated use is permitted. This zone is divided into three sub-zones: a) restricted use area, b) controlled use area, and c) traditional use area. The restricted use sub-zone is the most adjacent area to the protected zone and agricultural cultivations are not allowed. Light impact uses like bioprospecting or scientific studies such as this research are permitted. The controlled use sub-zone is immediately adjacent below the restricted use zone where minor forest product extraction is allowed. The latter was followed by the traditional sub-zone where the land was used in traditional ways (Table 2).

The multiple-use zone, on the other hand, is the lowermost portion of the project site. Its uses are actually similar to that of the traditional sub-zone, such as scattered patches of abaca and coconut plantations. 
Table 1. Physico-chemical properties of soil within the different zones of the study site

\begin{tabular}{llll}
\hline Parameters & \multicolumn{3}{c}{ Location } \\
\cline { 2 - 3 } & $\begin{array}{l}\text { Protected } \\
\text { Zone }\end{array}$ & Buffer Zone & $\begin{array}{c}\text { Multiple-use } \\
\text { zone }\end{array}$ \\
\hline pH & 5.97 & 5.10 & 6.57 \\
$\begin{array}{l}\text { Texture } \\
\text { Upper slope }\end{array}$ & Silt loam & Clay & Sandy loam \\
Middle slope & Loam & Silt loam & Clay loam \\
Lower slope & Silt loam & Sandy loam & Sandy loam \\
Bulk density $\left(\mathrm{Mg} / \mathrm{m}^{3}\right)$ & 0.72 & 0.61 & 0.78 \\
Carbon $\%\left(10-20 \mathrm{~cm}^{\text {depth }}\right)$ & 5.80 & 4.59 & 2.98 \\
Organic matter $\%$ & 10.00 & 7.92 & 5.14 \\
Total $\%$ & 0.67 & 0.58 & 0.29 \\
$\mathrm{P}(\mathrm{mg} / \mathrm{kg})$ & 144.00 & 162.00 & 265.00 \\
$\mathrm{~K}(\mathrm{mg} / \mathrm{kg})$ & 627.83 & 260.97 & 269.05 \\
$\mathrm{Na}(\mathrm{mg} / \mathrm{kg})$ & 159.80 & 125.79 & 136.77 \\
$\mathrm{Ca}(\mathrm{mg} / \mathrm{kg})$ & 2107.50 & 1354.25 & 5208.25 \\
$\mathrm{Mg}(\mathrm{mg} / \mathrm{kg})$ & 471.53 & 359.95 & 848.54 \\
\hline
\end{tabular}

Table 2. Land use classification of the CBFM project site (adopted from CRMF, undated)

\begin{tabular}{lll}
\hline Land Use Classification & Area (ha) & Percentage \\
\hline Protected Zone1, & 229.80 & 55.00 \\
Buffer Zone & 559.00 & 25.00 \\
Restricted use sub-zone & $(307.45)$ & $(55.00)$ \\
Controlled use sub-zone & $(167.70)$ & $(30.00)$ \\
Traditional use sub-zone & $(83.85)$ & $(15.00)$ \\
Multiple-use Zone & 447.20 & 20.00 \\
Total & $2,236.00$ & 100.00
\end{tabular}

\section{Field and laboratory methods}

\section{Upperstorey biomass carbon}

A total of $27(20 \mathrm{~m} \times 20 \mathrm{~m})$ purposive sampling plots were laid out within the study sites: 9 plots within the protected zone, 9 within the buffer zone, and 9 within the multiple-use zone. Tree heights, diameters, and local names were recorded. The biomass of trees with at least a diameter at breast height (dbh) of $10 \mathrm{~cm}$ and above (after Brown, 1997 and Lasco and Sales, 
2003) was calculated using the allometric equation below (adopted from Brown, 1997):

$\mathrm{Y}=\exp [-2.134+2.530 * \ln (\mathrm{D})]$ (equation 1)

where: $\mathrm{Y}=$ biomass per tree in $\mathrm{kg}$

$\mathrm{D}=\mathrm{dbh}$ in centimeters

Biomass of palms was calculated using the formula of Frangi and Lugo (1985) cited by Brown (1997):

$\mathrm{Y}=10.0+6.4 * \mathrm{TH}$

(equation 2)

where: $\mathrm{Y}=$ biomass in $\mathrm{kg}$

$\mathrm{TH}=$ total height in $\mathrm{m}$

$10+6.4=$ constant

Carbon content was calculated by multiplying the biomass value with 45 percent as suggested by Lasco (2003) and Sales-Come (2004).

* purposive sampling is a strategy of selecting sampling sites which the researcher believes to be the most representative for the whole area under study.

\section{Understorey biomass}

To determine the understorey biomass, three subplots measuring $2 \mathrm{~m} \mathrm{x}$ $2 \mathrm{~m}$ were randomly laid out within plots 1,5 , and 9 in all zones. All individual trees below $10 \mathrm{~cm}$ dbh as well as woody vegetation found within were harvested. Fresh weights of leaves, twigs, branches, and stems were determined and representative samples were separated for oven-drying.

A kg of freshly cut and mixed stems, twigs, and branches and a $\mathrm{kg}$ of fresh leaves were obtained from the field for air-drying. After a week of airdrying, 100-g samples from each biomass group were obtained for ovendrying. The oven-dried weight of the original biomass samples was then obtained through ratio and proportion. 


\section{Forest litter carbon}

Forest litters were collected from the three randomly laid out ( $1 \mathrm{mx} 1 \mathrm{~m})$ subplots within the 27 main plots. Collected litter samples from the three subplots were mixed together, fresh weights determined in the field, and representative samples were obtained for oven-drying.

\section{Root biomass}

Three soil pits measuring $1 \mathrm{~m} \times 1 \mathrm{~m} \times 1 \mathrm{~m}$ were dug within the randomly selected plots 1, 5, and 9 under each zone. From these pits, all plant roots visible to the naked eyes were collected. Fresh weights of the said roots were determined in the field and representative samples for oven-drying were obtained.

The mathematical model of Cairns et al. (1997) below was also used to calculate the carbon stock found in the root biomass for comparative purposes.

$$
\text { Root biomass }=\operatorname{Exp}[-1.0587+0.8836 \ln (\mathrm{AGB})]
$$

(equation 3)

where: $\mathrm{AGB}=$ aboveground biomass

All biomass samples were oven-dried for four days at constant temperature of $103{ }^{\circ} \mathrm{C}$. When the constant dry weights were attained, biomass samples were brought to the International Rice Research Institute's (IRRI) Analytical Service Laboratory at Los Baños, Laguna for grinding and carbon analyses. The Stainless Cross Beater Grinder and the Vibrating Sample Mill were used to grind the samples thoroughly while the Elemental Analyzer was used for carbon analyses.

\section{Soil carbon}

The soil organic carbon dynamics were analyzed along the various depths $(0-30,30-60,60-100 \mathrm{~cm})$ of the soil pits. Soil bulk density (BD) was determined within the plot before digging using the core sampling method. The soil organic carbon (SOC) was analyzed through the Walkley-Black method and calculated using the equation below: 
Total SOC $\left(\mathrm{Mg} \mathrm{ha}^{-1}\right)=\sum_{\mathrm{i}=1}^{\mathrm{n}}\left(\% \mathrm{SOC}^{*}\right.$ specified soil depth $\left.* \mathrm{BD}_{\mathrm{i} *}(1-\text { stone } \%)_{\mathrm{i}}\right) *$ factor (equation 4) where: $\mathrm{i}=$ soil depth $(0-30 \mathrm{~cm}, 30-60 \mathrm{~cm}, 60-100 \mathrm{~cm})$

Factor $=$ conversion value into one-hectare area

The BD used in calculating the soil carbon stock from the soil surface down to $30 \mathrm{~cm}$ depth $(0-30 \mathrm{~cm})$ was based from the results obtained through core sampling method. From $30 \mathrm{~cm}$ down to $100 \mathrm{~cm}$, the BD used was based on the assumed value of $1 \mathrm{Mg} / \mathrm{m}^{3}$. Core samples for BD determination were not undertaken at these depths due to soil compaction caused by digging operation. The assumed value was based on the observation that soil particles at such depth were higher than the ground surface due to eluviation and illuviation processes.

\section{RESULTS AND DISCUSSION}

\section{Carbon storage}

The various strata within the different zones of the CBFM project site showed varied trends in carbon stocks. The buffer zone had the highest upperstorey biomass carbon density because such zone had the highest volume of standing trees among the three (Figure 1). The multiple-use zone, on the other hand, having the lowest upperstorey carbon stock had less volume of standing trees among the three. Although considerable cover of vegetation is still present in the said zone, it has lesser number of trees compared to the other zones. According to the key informants, the zone in the past had been subjected to small-scale logging operation by the local people for building houses and other light structures because of the area's accessibility. What remains are naturally regenerating, small- to medium-sized plants. However, statistical analysis showed that carbon storage of the three sites is not significantly different (Tables 3 and 4 ).

In addition, only the understorey biomass carbon showed variation (Figure 2). The multiple-use zone had slightly more carbon stocks among the three zones which were attributed to the higher number of understorey plants. However, the stock of leaf biomass carbon within the understorey vegetation of the multiple-use zone was the least among the three zones (Figure 3). The leaves in the said zone appeared to be succulent compared to plants in the 


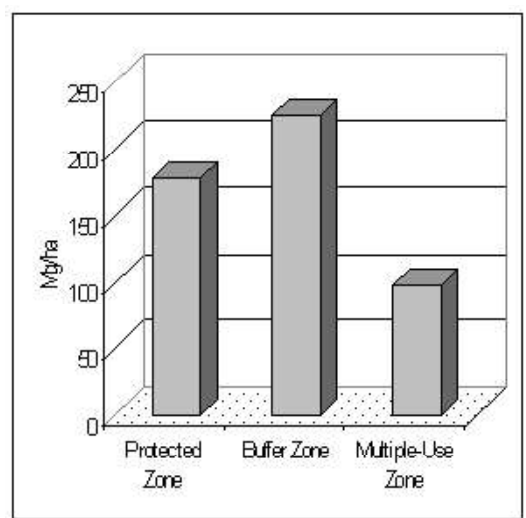

Figure 1. Upperstorey carbon density within the different zones of the study site

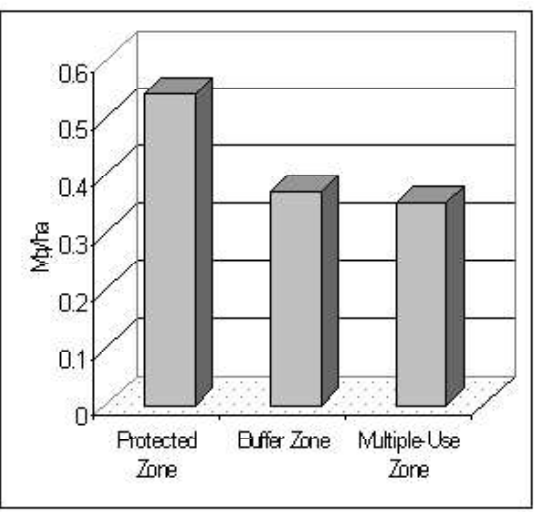

Figure 3.Carbon density in the leaf biomass of the understorey vegetation within the different zones of the study site

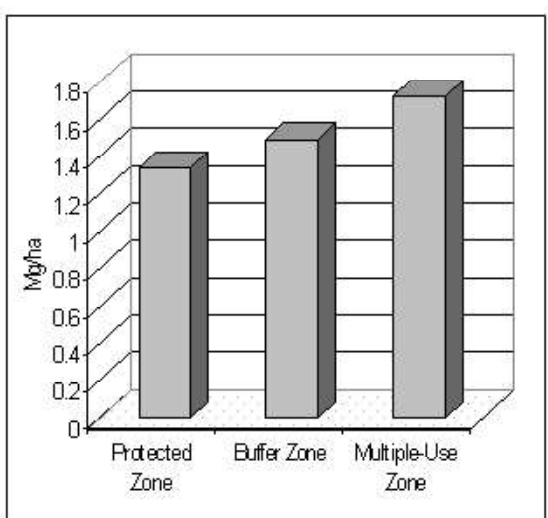

Figure 2. Carbon density in stems, twigs, and branches within the understorey vegetation

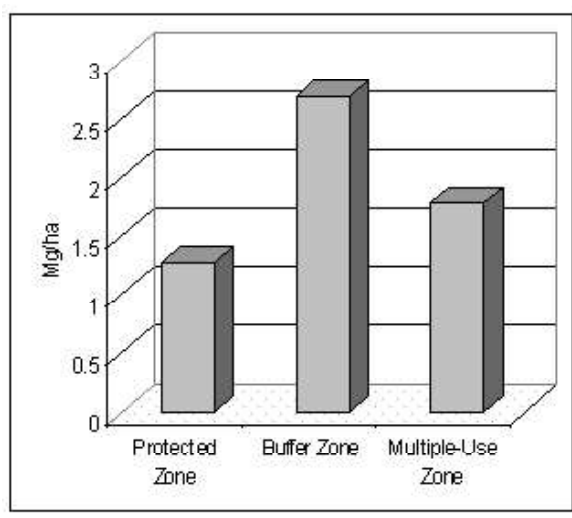

Figure 4. Carbon density in the litter biomass within the different zones of the study site 
Table 3. Total carbon stocks within the different zones of the CBFM Project (2005)

\begin{tabular}{llcc}
\hline Carbon Pools & \multicolumn{2}{c}{ Location/Carbon Stocks (Mg/ha) } \\
\cline { 2 - 4 } & Protected Zone & Buffer Zone & $\begin{array}{c}\text { Multiple-Use } \\
\text { Zone }\end{array}$ \\
\hline Upperstorey Biomass & $177 \mathrm{a}$ & $223 \mathrm{a}$ & $96.8 \mathrm{a}$ \\
Stem/Twigs (Understorey) & $1.34 \mathrm{a}$ & $1.49 \mathrm{a}$ & $1.72 \mathrm{a}$ \\
Leaves (Understorey) & $0.54 \mathrm{a}$ & $0.37 \mathrm{a}$ & $0.35 \mathrm{a}$ \\
Floor Litter & $1.38 \mathrm{~b}$ & $2.75 \mathrm{a}$ & $2.31 \mathrm{a}$ \\
Roots & $11.0 \mathrm{a}$ & $13.6 \mathrm{a}$ & $17.43 \mathrm{a}$ \\
Soil & $221 \mathrm{a}$ & $114 \mathrm{~b}$ & $111 \mathrm{~b}$ \\
Total & 413 & 356 & 229 \\
\hline
\end{tabular}

* number followed by a common letter are not significantly different based on HSD at $=5 \%$

Table 4. Analysis of variance

\begin{tabular}{|c|c|c|c|c|c|c|}
\hline Parameters & Grouping & Sum of Squares & $\mathrm{df}$ & Mean square & $\mathrm{F}$ & Sig. \\
\hline \multirow[t]{3}{*}{ Upperstorey } & Between groups & 118902783.519 & 2 & 59541391.760 & \multirow[t]{3}{*}{1.671} & \multirow[t]{3}{*}{$.209 \mathrm{~ns}$} \\
\hline & Within groups & 854130407.323 & 24 & 35588766.792 & & \\
\hline & Total & 973033190.842 & 26 & & & \\
\hline \multirow[t]{3}{*}{ Floorlitter } & Between groups & 8.813 & 2 & 4.406 & \multirow[t]{3}{*}{7.577} & \multirow[t]{3}{*}{$.003 * *$} \\
\hline & Within groups & 13.957 & 24 & .582 & & \\
\hline & Total & 22.769 & 26 & & & \\
\hline \multirow[t]{3}{*}{ Stem/twigs } & Between groups & .220 & 2 & .110 & \multirow[t]{3}{*}{1.44} & \multirow[t]{3}{*}{$.868 \mathrm{~ns}$} \\
\hline & Within groups & 4.575 & 6 & .762 & & \\
\hline & Total & 4.795 & 8 & & & \\
\hline \multirow[t]{3}{*}{ Leaves } & Between groups & .063 & 2 & .032 & \multirow[t]{3}{*}{.720} & \multirow[t]{3}{*}{$.525 \mathrm{~ns}$} \\
\hline & Within groups & .265 & 6 & .044 & & \\
\hline & Total & .328 & 8 & & & \\
\hline \multirow[t]{3}{*}{ Roots } & Between groups & 62.329 & 2 & 31.164 & \multirow[t]{3}{*}{.529} & \multirow[t]{3}{*}{$.614 \mathrm{~ns}$} \\
\hline & Within groups & 353.180 & 6 & 58.863 & & \\
\hline & Total & 415.509 & 8 & & & \\
\hline
\end{tabular}

other zones although during the double grinding process at IRRI, all leaf samples came out with similar appearances and texture. Statistical analysis however showed that both biomass carbon of stem/twigs/branches and leaves of the understorey vegetation are not significantly different.

The floor litter carbon stocks again showed varied trends. This time, the buffer zone had the highest amount of carbon among the three (Figure 4). During the actual sample collection period, the buffer zone had the thickest and driest floor litters among the three zones. Floor litters from the other zones, on the other hand, were thinner and showed higher degree of decomposition, particularly in the protected zone. In fact, statistical analysis 
showed that floor litter within the protected zone is significantly lower compared with the other two zones.

Furthermore, the multiple-use zone had the highest root biomass carbon (Figure 5) basedfrom the actual result obtained from the randomly laid soil pits. Using equation 3 , however, the estimated root biomass carbon density was higher compared to the actual results obtained. The protected zone had $34.08 \mathrm{Mg} /$ ha, the buffer zone had $41.65 \mathrm{Mg} / \mathrm{ha}$, and the multiple-use zone had $20.10 \mathrm{Mg} /$ ha carbon density. Because of such significant variation, there seemed to be a need to further study the root biomass and carbon density of the site by increasing the number of sampling pits. The researcher failed to obtain more root biomass samples as the bio-prospecting law of DENR was being implemented by the people's organization managing the CBFM Project.

Statistically, the three sites had no significant difference. Nonetheless, what appeared to be important was that root biomass had significant contribution in carbon storage.

Likewise, the soil carbon which occupied a significant portion of forest carbon and could contain as much carbon as the biomass (Lasco, 2003) was also determined. Results showed that soil carbon was higher compared with the biomass carbon except in the buffer zone where the volume of standing trees was relatively high. Obviously, soil carbon is higher than the aboveground biomass because falling debris or litter, dead plant roots as well as animal wastes and dead remains will decompose and join the soil complex. Such finding was corroborated by the findings of Batjes (1996) that soil carbon was four times more than that of the aboveground biomass. Statistically, soil carbon at the protected zone was significantly higher than the other zones (Tables 5 and 6). However, a large portion of this carbon content was present only on the upper soil horizon (Figure 7 and Table 6). Soil disturbance like logging and subsequent erosion will easily release carbon to the atmosphere and consequently contribute to global warming. Nevertheless, the effort of the project through the CBFM members to protect the area against logging and kaingin has continually controlled the release beyond normal of carbon to the atmosphere.

Overall, the protected zone contained the highest total carbon stocks among the three zones (Figure 8). However, such finding is very temporary. When climax vegetation stage is attained, all zones may show closely similar stocks of carbon. Houghton et al. (1997) estimated the aboveground biomass carbon of the Philippine old-growth and secondary dipterocarp forests to be 


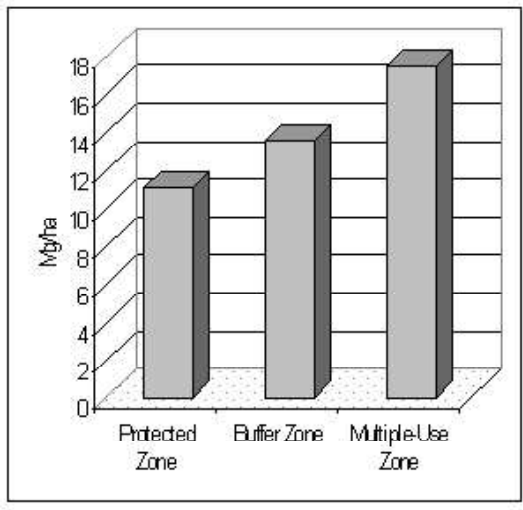

Figure 5. Carbon density in the root biomass within the different zones of the study site

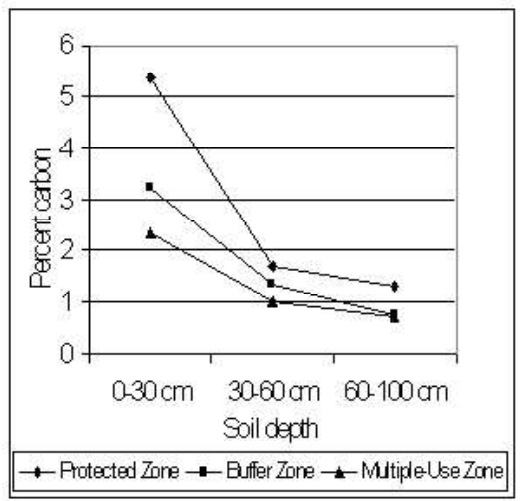

Figure 7. Percent carbon found at various soil depths within the different zones of the study site

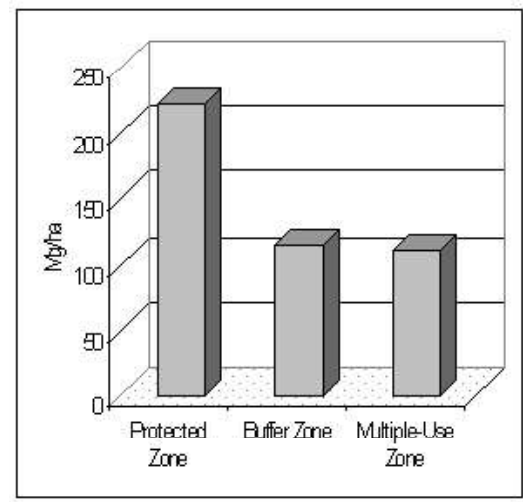

Figure 6. Carbon density in the soil complex within the different zones of the study site

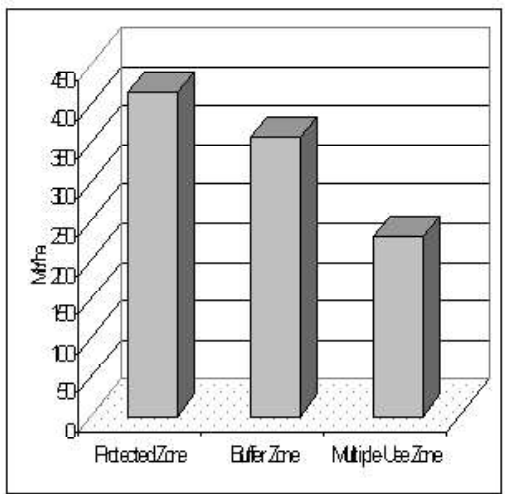

Figure 8. Total carbon density within the different zones of the study site 
Table 5. Univariate analysis of soil carbon across different zones and soil depths

\begin{tabular}{llllll}
\hline Source & df & Sum of squares & Mean Square & F & Sig \\
\hline Zone & 2 & 7880.787 & & & \\
Depth & 2 & 7272.494 & 3940.394 & 7.002 & $.006^{* *}$ \\
Zone*Depth & 4 & 3540.516 & 3636.247 & 6.462 & $.008^{* *}$ \\
Error & 18 & 10129.028 & 885.129 & 1.573 & $.224 \mathrm{~ns}$ \\
Total & 26 & 28822.825 & 562.724 & & \\
\hline
\end{tabular}

Table 6. HSD analysis of soil carbon across different zones and soil depths

\begin{tabular}{llll}
\hline Location & Zonal Analysis & Soil Depth & Depth Analysis* \\
\hline & & & \\
Protected zone & $73.9 \mathrm{a}$ & $0-30 \mathrm{~cm}$ & $72.8 \mathrm{a}$ \\
Buffer zone & $38.3 \mathrm{~b}$ & $30-60 \mathrm{~cm}$ & $40.1 \mathrm{~b}$ \\
Multiple-use zone & $37.0 \mathrm{~b}$ & $60-100 \mathrm{~cm}$ & $36.3 \mathrm{~b}$ \\
\hline $\begin{array}{l}* \text { number followed by a common letter are not significantly different based on HSD at } \\
\quad=5 \%\end{array}$
\end{tabular}

370-520 and 300-370 Mg/ha, respectively. Results from this study showed an average aboveground biomass carbon storage of only $169.99 \mathrm{Mg} / \mathrm{ha}$. However, the study site is not purely occupied with dipterocarps but a mixture of different species. Nevertheless, the estimates of Lasco and Pulhin (2000) for protection and secondary forests showed closer values with the calculated carbon stocks in this study.

\section{Livelihood opportunities}

Results from the investigations clearly revealed the huge amount of carbon stock being stored at the various strata of the said ecosystem. Comparatively, grasslands in the Philippines have only an average carbon storage of $5.0 \mathrm{Mg} /$ ha (Lasco and Pulhin, 2000) which is far below from the findings of this study. Without the people's organization protecting it, forest may be converted into grasslands.

The sustainability of such environmental service from these projects is bound to fail if the people working under them would lose their desire to continue protecting the forest. Based on previous experiences, members of people's organizations $(\mathrm{PO})$ easily lose their enthusiasm simply because of the delayed release of funds for the project. More so if nothing would compensate for their continuous forest protection activities. With the dwindling financial support from the Philippine government for the said projects, the motivating 
element to sustain would be rewards or livelihood opportunities from the beneficiaries of environmental services or sources other than the government. On the other hand, the government may create non-monetary rewards (due to financial crisis) to sustain the CBFM projects and such associated environmental service.

Rewarding has become an emerging issue in view of sustaining environmental services from forestry and agroforestry initiatives. It is hypothesized that the environmental services can be sustainable if those who produce such services will receive certain forms of rewards. Therefore, the difficult task of the upland people in protecting the forests to produce environmental services can be compensated, thus keeping them enthusiastic in upholding their valuable and revenue-generating endeavors. According to Wunder (2005), carbon sequestration and storage has significant commercial value at present wherein a Northern electricity company is paying farmers in the tropics for planting and maintaining additional trees.

In addition, Calderon (2002) pointed out that despite the uncertainties regarding the inclusion of carbon forestry projects under Clean Development Mechanism (CDM), many parties are already engaging in carbon forestry trading (Table 6). The projects are basically focused on reforestation, afforestation, and modified forest harvesting methods, which can possibly qualify under CDM. The above projects show that trade in forestry carbon has begun despite the fact that there is still no certainty that these would be credited under CDM of the Kyoto Protocol. While the cost per $\mathrm{tC}$ varies (from as low as US\$4/tC to as high as US\$353/tC), it is clear that substantial amounts of money are involved. In Australia, the Sydney Futures Exchange has already established a carbon credits trading market, and so far, many carbon emitter are already buying credits from forest growers (AAS n.d cited by Calderon, c.2002). It should be noted that issuance of resource utilization permit (RUP) has been suspended and the financial support to sustain CBFM could largely be generated from rewards or payments from its environmental services like carbon storage.

\section{RECOMMENDATION}

Further studies should be undertaken to determine whether trading of forest environmental services like carbon could really provide significant livelihood improvement. One possible study using economic models would be a comparative research (scenario-building) between carbon payments against 
the annual income from agronomic crops, pasture, or other traditional land use. This study can help identify what land use would be more profitable for the farmers or service providers taking into consideration the sustainable generations of forest environmental services like carbon storage.

\section{ACKNOWLEDGMENT}

The author is grateful to the Southeast Asian Regional Center for Graduate Study and Research in Agriculture (SEARCA) and the German Academic Exchange Service (DAAD) of the Federal Republic of Germany for the financial support, and the Commission on Higher Education (CHED) of the Republic of the Philippines for the dissertation grant. He is also indebted to Dr. Teodoro R. Villanueva, Dr. Wilfredo M. Carandang, Dr. Myrna G. Carandang, and Dr. Juan M. Pulhin for their technical assistance. Likewise, he is thankful to the people's organization (CSVFA) for allowing him to conduct the research in their CBFM project.

\section{LITERATURE CITED}

ASIO, V. B. 1996. Characteristics, weathering, formation and degradation of soils from volcanic rocks in Leyte. Hohenheimer Bodenkundliche Hefte 33, Stuttgart. 209 pp.

BROWN, S. 1997. Estimating Biomass and Biomass of Tropical Forest: A Primer. FAO Forestry Paper No. 134. Rome: Food and Agriculture Organization. 55pp.

BATJES, N.H. 1996. Total carbon and nitrogen in the soils of the world. European Journal of Soil Science. 47:151-163.

CAIRNS, M.A., S. BROWN, E.H. HELMER and G.A. BAUMGARDNER. 1997. Root biomass allocation in the world's upland forests. Oecologia. 111: 1-111.

CALDERON, M.M. 2002. Opportunities and challenges for a carbon market for the Philippine Forestry Sector. Journal of Environmental Science and Management. 4(1-2): 14-28

CARANDANG, W.M. 1994. Lateral Root Development and Seedling Performance of Large-Leaf Mahogany (Sweitenia macrophylla King). PhD Dissertation. College of Forestry and Natural Resources, University of the Philippines Los Baños, Laguna, Philippines.

CRMF. Undated. Community-based forest management project profile. Cienda, Gabas, Baybay, Leyte: Cienda-San Vicente Farmers Association. 
DENR. Undated. Frequently Asked Questions about Community-Based Forest Management. Diliman, Quezon City: CBFM Office, DENR.

FIELD, C.B. 1997. Environmental Economics: An Introduction. New York: Irwin/McGrawHill.

HOUGHTON, J.T., F. L. G. MEIRA, B. LIM, K. TREANTON, I. MAMATY, Y. BONDUKI, D.G. GRIGGS and B.A. CALLANDER (Eds.). 1997. Greenhouse Gas Inventory Workbook. Intergovernmental Panel on Climate Change. Paris, France: Organization of Economic Cooperation and Development (OECD) and the International Energy Agency (IEA).

IPCC. 1995. Climate Change. Cambridge, UK: Cambridge University Press.

LASCO, R.D. 2003. Laboratory Guide on Forest Soils and Climate Change. Los Banos: Institute of Renewable Natural Resources. College of Forestry and Natural Resources. UP Los Baños, Laguna, Philippines.

LASCO, R.D. and F.B. PULHIN. 2000. Forest land-use change in the Philippines and climate change mitigation. Mitigation and Adaptation Strategies to Global Change Journal 5: 81-97.

LASCO, R. D. and R. SARES. 2003. Personal Communication. Environmental Forestry Program(ENFOR). UPLB, Laguna, Phil.

LEAN, G., D. HINRICHSEN, and A. MARKHAM. 1990. WWF Atlas of the Environment. New York, NY: Prentice Hall Press.

MAGCALE-MACANDOG, D.B. 2000. Status of the GHG inventory for the LUCF sector in the Philippines, Thailand, and Indonesia. Proceedings of the IGES/NIES workshop on GHG inventories for Asia-Pacific Region. Japan: Institute for Global Environmental Strategies.

MOURO-COSTA, P. 1996. Tropical practices for carbon sequestration. A. Zchulte \& S. Schone (eds). Dipterocarp Forest Ecosystems: Towards Sustainable Management. Singapore : World Scientific. p. 308-334.

RUPES. 2002. Primer on Developing Mechanisms for Rewarding the Upland Poor in Asia for Environmental Services They Provide. Los Baños: ICRAF (now World Agroforestry Center.

SALES-COME, R. F. 2004. Personal communication on carbon stock assessment. Formerly connected with the Environmental Forestry Program (ENFOR). University of the Philippines Los Baños. Laguna, Philippines.

SCHERR, S.J., A. WHITE and D. KAIMOWITZ. 2004. A new agenda for forest conservation and poverty reduction: Making markets work for low-income producers. Forest Trends. USA: Washington D.C.

WUNDER, S. 2005. Payments for Environmental Services: Some Nuts and Bolts. Jakarta, Indonesia: Center for International Forestry Research (CIFOR). 